\title{
Properties of Jambi tempoyak; The effects of salts concentration
}

\author{
Addion Nizori ${ }^{1}$, Mursalin ${ }^{2}$ \\ \# Addion Nizori is with Agricultural technology of product Department, Agricultural technology faculty, Jambi University, Jambi, 36122, Indonesia. (e-mail: \\ addionnizori@unja.ac.id). \\ Mursalin is with 'Agricultural Engineering Department, Jambi University, Jambi, 36122, Indonesia. (e-mail: mursalin@unja.ac.id).
}

\begin{abstract}
Tempoyak was made from fermented durian flesh, which very popular among Jambi people Indonesia. This study aims to isolate and identification of bacteria developed during fermentations process, determine physical-chemical properties of tempoyak as the effect of adding salts at various concentration and the sensory evaluations of tempoyak produced is also evaluated. The predominants microorganisms present in tempoyak were Lactobacillus bacteria. The results also showed that the level of salts concentration has a significant effect on $\mathrm{pH}$, lactic acid content, however, has not significant impact on sensory evaluations. The best results was $3 \%$ of adding salts with the product properties of $\mathrm{pH} 3.64$, lactic acid content $3.11 \%$ and overall acceptance score is 3.41 .
\end{abstract}

Keywords - Tempoyak, fermented foods, salts and sensory

\section{INTRODUCTION}

Tempoyak is traditionally fermented food from durians flash which is a popular acid-fermented condiment used with certain fish and vegetable dishes in ASEAN countries, including Jambi Indonesia. Durian flash is traditionally fermented through spontaneous and uncontrolled processes these will lead to variable quality, as the indigenous microflora is not consistent [4].

Durian pulp from different durians is mixed with or without addition of salt and allowed to ferment in tightly container at room temperature for a minimum of seven days for the development of acidity and flavour [14].

LAB are predominant microorganisms present in tempoyak ranging from 8.4 to $9.2 \mathrm{log}$ CFU/g of tempoyak [11]. They had reported that lactobacillus plantarum were the predominant members of the LAB flora in tempoyak.

Previous studies on tempoyak mainly only focused on the microbial aspect of tempoyak [7] [16] [17]. The effect of traditional process making tempoyak with adding salts to the physio-chemical properties and sensory evaluation of tempoyak, however, have not been reported. As various adding salts concentration might affect physio-chemical, sensory as well as changes of microbial properties during tempoyak fermentation.

The aims of this research were to study the effects of salts concentration into microbiological and physio-chemical properties of tempoyak. In addition, the sensory properties of fermented tempoyak is also evaluated.

\section{MATERIAL AND MethodS}

\section{A. Materials}

All chemicals used for analytical procedures were analytical grade or the highest purity available. Details of chemicals and suppliers were MRSA (Merck), MRS Broth (Merck), APDA (Merck), RCA (Merck), HCL, NaCL, NaOH. $\mathrm{CaCO}_{3}$ hydrogen peroxide and Gram test kits.

\section{B. $\quad$ Preparation of making tempoyak}

Durian fruit was obtained from local market at Jambi, Indonesia. Fermented durian was prepared in accordance with traditional method of fermentation. Durian pulp (400 g) was mixed with salt according to the treatments $(0,1 \%, 2 \%, 3 \%$ and $4 \%$ by weight) and was placed it in sealed plastic containers. The durian was allowed to spontaneously ferment during 7 days at room temperature $\left(31^{\circ} \mathrm{C}\right)$. Three replications were maintained in this experiment.

\section{LAB Isolation and identifications}

The LAB isolation method was according to Hayakawa (1992) [8].with some modifications. Tempoyak was made at 0 , $1 \%, 2 \%, 3 \%$ and $4 \%$ was taken each of samples $(10 \mathrm{~g})$ and blended with $100 \mathrm{ml}$ of $0.85 \% \mathrm{NaCl}$ solutions aseptically; 10 $\mathrm{ml}$ of this blended food was added to $100 \mathrm{ml}$ MRS broth (de Man et al, 1960) in a $250 \mathrm{ml}$ erlemeyer flask. The flask were shaken in an incubator for 48 hours at $37^{\circ} \mathrm{C}$. Then aliquots of the culture from each flasks were diluted serially to $10^{6}$ times and $0.1 \mathrm{ml}$ was spread evenly on MRS agar plates. The plates were incubated for 2 days at room temperature. Bacterial 
colonies that developed on the plates were individually picked and streaked on fresh MRS agar plates by dilution streaking to obtain single colonies. This procedure was repeated in order to purify the isolates. Each of the isolates was tested for catalase by placing a drop of $3 \%$ hydrogen peroxide solution on the cells. Immediate formation of bubbles indicated the presence of catalase in the cells. Only those isolates, which were catalase negative, were Gram-stained [10].

\section{Sensory properties of tempoyak}

Sensory analysis was performed in the Food Microbiology Laboratory, University of Jambi. A panel of 15 semi-trained panelists evaluated sensory attributes of the tempoyak was made at various salts concentration.

The panelists were selected from among students, faculty and staff to evaluate each tempoyak sample on the following sensory characteristics: color, texture, aroma, taste and overall acceptance.

A 5-point hedonic scale. Taste: from 1 to 5 (not sour into very high sour);Colour: from 1 to 5 (light yellow into very dark yellow);Texture: from 1 to 5 (not firm into very high firm);Flavour: from 1 to 5 (weak flavour into very strong flavour);Overall: from 1 to 5 (dislike into very like).

\section{RESUlT AND DISCUSSION}

\section{A. LAB Isolation and identification}

Based on the results showed that all of lactic acid bacteria isolated from Tempoyak Jambi origin with various salts concentrations shows the characteristics of spherical-shaped colonies, milky white color of the colonies, positive Gram (+), negative catalase reaction, short rod-shaped cell with dark purple color as seen in Figure 1 and Table 1.

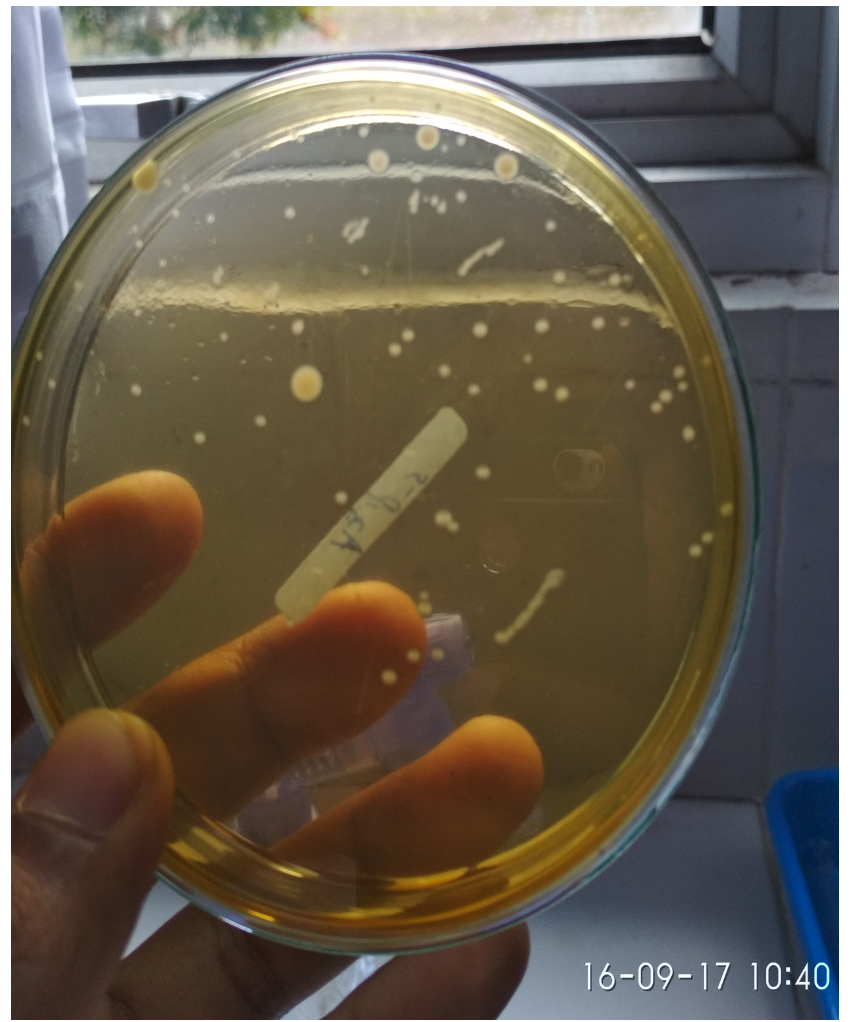

Figure 1. Lactic acid bacteria isolated from Tempoyak Jambi origin with various salts concentrations shows the characteristics of spherical-shaped colonies, milky white color of the colonies.

Table 1. LAB screening profile based on morphological and physiological from Tempoyak made from various

\begin{tabular}{cccc}
\multicolumn{3}{c}{ salts concentrations. } \\
$\begin{array}{c}\text { Salts } \\
\text { conc } \\
(\%)\end{array}$ & form & Gram & Catalase test \\
\hline 0 & $\begin{array}{l}\text { Rods, } \\
\text { cocci }\end{array}$ & $(+)$ & $(-)$ \\
1 & $\begin{array}{l}\text { Rods, } \\
\text { cocci }\end{array}$ & $(+)$ & $(-)$ \\
2 & $\begin{array}{l}\text { Rods, } \\
\text { cocci } \\
\text { Rods, } \\
\text { cocci }\end{array}$ & $(+)$ & $(-)$ \\
3 & $\begin{array}{l}\text { Rods, } \\
\text { cocci }\end{array}$ & $(+)$ & $(-)$ \\
4 & & $(-)$ \\
\hline
\end{tabular}

The LAB pictures from tempoyak made from various salts concentration under Microscope is shown in Figure 2. 


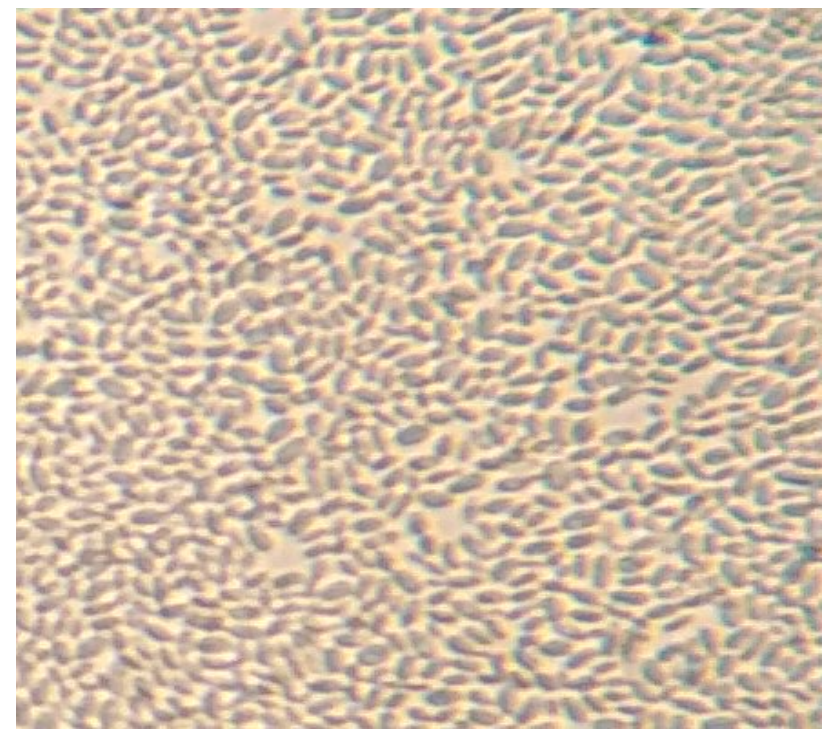

Figure 2. LAB pictures from tempoyak made from various salts concentration under Microscope.

The isolation, identification and screening of microorganisms from natural sources has always proved to be a successful way for obtaining industrially important strains or strains with valuable industrial and medical applications [15].

\section{B. Physical-chemical properties}

Based on the physical-chemical properties showed that lactic acid bacteria isolated from Tempoyak Jambi origin with various salts concentrations shows the characteristics of have different range of $\mathrm{pH}$, total acid lactic, $\mathrm{LAB}$ count, however the same colour and form of LAB colony as general colour and form of LAB colony (Table 2).

Table 2. LAB screening profile based on physical-chemical properties from Tempoyak made from various salts concentrations.

\begin{tabular}{|c|c|c|c|c|c|}
\hline $\begin{array}{l}\text { Salts } \\
\text { conc } \\
(\%)\end{array}$ & $\begin{array}{l}\text { Lactic } \\
\text { Acid } \\
(\%)\end{array}$ & $\mathrm{pH}$ & $\begin{array}{l}\text { LAB count } \\
(\mathrm{CFU} / \mathrm{mL})\end{array}$ & Colour & form \\
\hline 0 & 1.90 & 3.95 & $3,7 \times 10^{6}$ & $\begin{array}{l}\text { Milky } \\
\text { white }\end{array}$ & Round \\
\hline 1 & 2.95 & 3.71 & $6,4 \times 10^{6}$ & $\begin{array}{l}\text { Milky } \\
\text { white }\end{array}$ & Round \\
\hline 2 & 2.47 & 3.70 & $8,3 \times 10^{7}$ & $\begin{array}{l}\text { Milky } \\
\text { white }\end{array}$ & Round \\
\hline 3 & 3.11 & 3.64 & $2,3 \times 10^{6}$ & $\begin{array}{l}\text { Milky } \\
\text { white }\end{array}$ & Round \\
\hline 4 & 3.50 & 3.61 & $2,1 \times 10^{6}$ & $\begin{array}{l}\text { Milky } \\
\text { white }\end{array}$ & Round \\
\hline
\end{tabular}

LAB are acidophilic but while that means a tolerance to low $\mathrm{pH}$, the latter should be differentiated from a situation in which a high concentration of free acids $\left(\mathrm{H}^{+}\right)$also exists because the free acids could inhibit growth [3].

\section{Sensory properties}

The effect of addition of salts at various concentrations will have a significant effect on colour, taste, and texture however there is no significant impact on flavour of tempoyak. The effect of addition of salts concentrations at various levels into sensory properties of tempoyak is shown in Table 3 below.

Table 3. The effect of addition of salts concentrations at various levels into sensory properties of tempoyak

\begin{tabular}{cccccc}
\hline $\begin{array}{c}\text { Salts } \\
\text { conc } \\
(\%)\end{array}$ & Taste & Colour & Texture & Flavour & Overall \\
\hline 0 & 2.44 & 1.52 & 3.76 & 2.56 & 2.92 \\
1 & 2.48 & 1.80 & 3.74 & 2.61 & 3.20 \\
2 & 2.48 & 1.84 & 3.74 & 2.52 & 3.22 \\
3 & 2.41 & 1.92 & 3.60 & 2.56 & 3.41 \\
4 & 2.56 & 2.08 & 3.68 & 2.52 & 2.96 \\
\hline
\end{tabular}

Based on the sensory properties showed that lactic acid bacteria isolated from Tempoyak Jambi origin with adding various salts concentrations shows there was significant effect on colour at $1 \%$ to $4 \%$ compared with no added salts. We can see that the increasing of salts concentration will increase the hedonic scale of colour of tempoyak.

However the increasing of salts concentration have not much impact into taste, texture and flavour of tempoyak. The effect of addition of salts concentrations at various levels into sensory properties of tempoyak is shown on Figure 3 below.

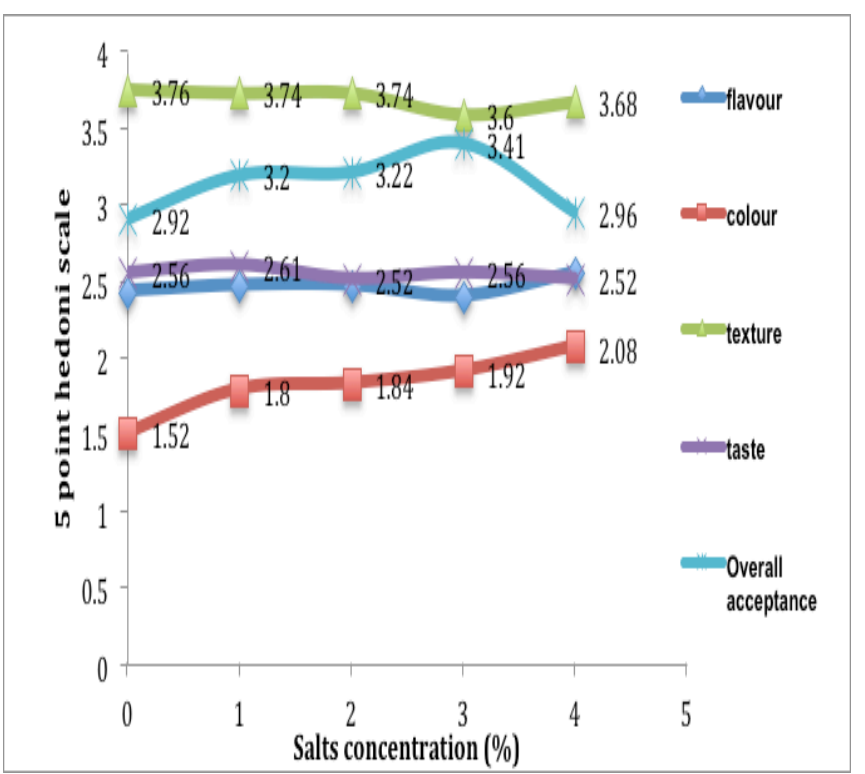

Figure 3. The effect of addition of salts concentrations at various levels into sensory properties of tempoyak 
From Figure 3 it can be seen that the tempoyak flavours were not much impact also with increasing of salts concentration. The changes of the flavor components were might attributed to the significant role of microorganisms during fermentation mainly lactic acid bacteria and could also the presence of indigenous enzymes in durian fruit that were still active. LAB presents in tempoyak (fermented durian) has been reported by some researchers [13] [1] [2].

In some cases, fermentation microorganisms might not directly involved in the formation of flavor. The example of this has been proposed in commercial sauerkraut fermentations [5] [15].

Figure 3 shows also that the increasing salts concentrations were increase overall acceptance of tempoyak from 1 to $3 \%$ concentration, however, the hedonic scale will decrease on $4 \%$. Tempoyak normally were produce using low-quality durian pulp obtained from crack, poor quality or over ripen durian, so production of tempoyak allows for the salvage of durians which would be otherwise be discarded [8]..

\section{CONCLUSION}

It can be concluded that there is a significant effect of adding salts at various concentration into microbiological, physio-chemical properties, however there is not significant impact on sensory evaluation of tempoyak.

\section{REFERENCES}

[1] Amin, M.A., Zakiah, J. and Khim, Ng. L. 2004. Effect of salt on tempoyak fermentation and sensory evaluation. Journal of Biology Science 4(5): 650-653.

[2] Amiza, M.A, Zakiah, J., Khim, N. L. and Lay, K.W. 2006. Fermentation of tempoyak using isolated tempoyak culture. Research Journal of Microbiology 1 (3): 243-254.

[3] Amrane, A., Prigent, Y., 1999. Differentiation of $\mathrm{pH}$ and free lactic acid effects on the various growth and production phases of Lactobacillus helveticus. J. Chem. Technol. Biotechnol. 74, 33-40.

[4] Chen, Y.-s.,Wu, H.-c., Pan, S.-f., Lin, B.-g., Lin, Y.-h., Tung,W.-c., Li, Y.-1., Chiang, C.-m., Yanagida, F., 2013. Isolation and characterization of lactic acid bacteria from yan-taozih (pickled peaches) in Taiwan. Ann. Microbiol. 63, 607e614.

[5] Daxenbichler, M.E., Van Etten, C.H., and Williams, P.H. 1980. Glucosinolate products in commercial sauerkraut. Journal of Agricultural and Food Chemistry 28:809-811.

[6] de Man, J.C., Rogosa, M., Sharpe, M.E., 1960. Medium for the cultivation of lactobacilli. J. Appl. Bacteriol. 23, $130-135$.
[7] Ekowati, C.N., 1998. Mikroflora pada fermentasi daging buah durian (tempoyak). J. Sains Dan. Teknol. Ed. Khusus 136e141.

[8] Gandjar, J., 2000. Fermentations of the far east. In: Robinson, R.K., Batt, C.A., Patel, P.D. (Eds.), Encyclopedia of Food Microbiology. Academic Press, New York, pp. 767e773.

[9] Hayakawa, K. 1992. Classification and Actions of Food Microorganism with Particular Reference to Fermented Foods and Lactic Acid Bacteria. dalam Yuji Nakazawa and Akiyoshi Hosono (Ed.). Functions of Fermented Milk: Challenges for the Health Sciences. London: Elsevier Science Publishers, Ltd.

[10] Kheadr, E. 2006. Impact of acid and oxgall and antibiotic susceptibility of probiotic lactobacilli. African Journal of Agricultural Research, I, 172-181.

[11]Leisner, J.J., Vancanneyt, M., Rusul, G., Pot, B., Lefebvre, K., Fresi, A., Tee, L.K., 2001. Identification of lactic acid bacteria constituting the predominating microflora in an acid fermented condiment (tempoyak) popular in Malaysia. Int. J. Food Microbiol. 63, 149e157.

[12]Leisner, J.J., Vancanneyt, M., Van der Meulen, R., Lefebvre, K., Engelbeen, K., Hoste, B., Laursen, B.G., Bay, L., Rusul, G., De Vuyst, L., Swings, J., 2005. Leuconostoc durionis sp. nov., a heterofermenter with no detectable gas production from glucose. Int. J. Syst. Evol. Microbiol. 55, 1267e1270.

[13] Leisner, J.J., Vancanneyy, M., Rusul, B., Lefebre, K., Pot, B., Lefebvre, K., Fresi, A. and Tee, L. K. 2001. Identification of lactic acid bacteria constituting the predominating micro flora in an acid-fermented condiment (tempoyak) in Malaysia. International Journal of Food Microbiology 63 (1-2):149-157.

[14] Merican, Z., 1977. Malaysian tempoyak. In: Steinkraus, K.H. (Ed.), Handbook of Indigenous Fermented Foods. Marcel Dekker, New York and Basel, pp. 147 - 148

[15] Viander, B., Mäki, M. and Palva, A. 2003. Impact of low salt concentration, salt quality on natural largescale sauerkraut fermentation. Food Microbiology 20 (4):391395.

[16] Yang, E., Fan, L., Jiang, Y., Doucette, C. \& Fillmore, S. 2012. Antimicrobial activity of bacteriocin-producing lactic acid bacteria isolated from cheeses and yogurts. AMB Express, 2, 48-59. http://dx.doi.org/10.1186/21910855-2-48

[17] Yuliani, N., Dixon, E.I., 2011. Phenotypic identification of lactic acid bacteria isolated from tempoyak (fermented durian) made in the Philippines. Int. J. Biol. 3, 145e152. 